\title{
Theoretical Review of Turnaround Strategy and Its Organizational Outcomes
}

\author{
Kenneth Ateng' Nyagiloh ${ }^{1} \&$ James M. Kilika ${ }^{1}$ \\ ${ }^{1}$ Department of Business Administration, School of Business, Kenyatta University, Kenya \\ Correspondence: Kenneth Ateng' Nyagiloh, Department of Business Administration, School of Business, \\ Kenyatta University, Kenya.
}

Received: October 10, 2019

Accepted: December 20, 2019

Online Published: January 3, 2020

doi:10.5539/ibr.13n2p13

URL: https://doi.org/10.5539/ibr.v13n2p13

\begin{abstract}
Strategic management literature has recognized the role of turnaround strategy in the management process as a critical strategy at the corporate level. Researches done on turnaround strategy and corporate performance have however been biased with respect to limited scope in terms of the dimensions of performance as well as the challenges in methodology and conceptualization that affect the generalization of the study findings. This paper undertakes a review of the extant literature on the conceptual, theoretical and empirical work that brings about a number of issues for use in presenting a case for the new theoretical model that is suitable for extension of the current understanding of deployment of turnaround strategy and the ultimate results. The paper suggests an integrated theoretical framework for use in linking turnaround strategy and corporate performance while recognizing the significance of the role of organizational turnaround-based learned experiences and organizational characteristics.
\end{abstract}

Keywords: turnaround strategy, organizational learning, organizational characteristics, corporate performance, organizational development, performance measures

\section{Introduction}

An organization's strategy describes the pursuit of goals by considering the environmental threats and opportunities and the available resources and capabilities (Nandakumar, Ghobadian , \& O'Regan, 2010). As such, strategic management is directed towards analyzing, collating and overcoming the problems faced by firms due to changes in the environment. Strategic management also examines the firm's rules that are set for decision making that guides the organizational activities (Petrova , 2017). Organizational strategies are formulated based on the levels of strategy of the firms that are hierarchically structured and relied upon so as to implement the strategies with the objective of achieving sustainable competitive advantage. The levels are Corporate, Business, and Functional. The firm's effective strategy therefore provides sustainable advantage that eventually results into a superior performance that is achievable when the strategy is aligned to external and internal structural conditions of the organization (Nandakumar, Ghobadian , \& O'Regan, 2010, Chandler, 1962).

Corporate level strategies define the strategic position of the entire business organization and set out the general directions of development of its activities and focuses on the type of business that will develop according to its potential. The strategies here are of three forms: development, stabilization and survival. Business level strategies define the firm's deployment of the resources in the respective products or markets and include market and product development, concentration and integrations. Functional level strategies emphasize on the implementation of basic functions in the entity and include production, financial, marketing research and trade (Nandakumar, Ghobadian , \& O'Regan, 2010, Petrova , 2017). A strategy is therefore considered effective if it provides sustainable advantage to an organization that eventually results into a superior performance which is achievable by matching the strategy with the organization's external environment and internal conditions. Strategic management literature suggests that a successful firm's strategy and structure must be favorably aligned with the external environment (Nandakumar, Ghobadian , \& O'Regan, 2010).

A number of grand strategies are formulated by corporates that are geared towards the provision of direction for strategic actions. The grand strategies are comprehensive plans that provide foundation for coordinated and sustained efforts for the achievement of long-term corporate objectives. Firms can make use of a combination of various grand strategies in order to achieve the set objectives. The most common grand strategies adopted by 
firms in the respective situations include: Concentrated growth strategy which focuses on the firm's resources on the profitable growth; Market development strategy which involves selling the present products into new markets; Product development strategy which involves substantial modification of existing products; Innovation strategy that involves creating new product life cycle and Strategic alliance strategy involving the creation of partnership between two or more independent firms (Fadun, 2014).

At the corporate level, strategies seeking to attain survival become the basis for strategic options for a turnaround under situations in which firms could be going through financial distress (Nandakumar, Ghobadian , \& O'Regan, 2010). Turnaround research recognizes a number of dilemmas that surround the adoption and application of turnaround strategies including the firm's capability to adapt to the environment, management skills for the crisis, the structure of the organization, resource dependency, alternative strategies, and the external and internal impacts of the crisis that are considered very critical for reversing the poor performance. The failure to adjust to these environmental factors have the effect of deteriorating the firm's performance (Tikici, Omay, Derinc, Seckin, \& Cureoglu, 2011)

Turnaround strategies require firms to undergo increased market analysis so as to undertake risky actions in order to effect an organizational recovery (Whitney, 1987; Morrow, JR., Sirmon, Hitt, \& Holcomb, 2007). The understanding of the company strategy in the phase of crisis therefore requires the business managers to understand causes of decline, turnaround strategy and the required responses to the decline since turnaround strategies must depend upon the source of decline and the need to acknowledge both the internal and external problems of the firm (Pearce II \& Robbins, 1993; Kazozcu, 2011; Santana, Valle, \& Galan, 2018).

Turnaround strategy has a functional role in the organization that is achieved through its deployment at the corporate level that is meant to incorporate the strategic intent to show the clear vision of the firm; the breakthrough objectives; priority initiatives and accountability for all the firm's initiatives (Finerty, 2014). These actions are aimed at resulting into enhanced labour relations, maximization of resource productivity, stringent working capital and maximized capacity utilization of the firm (Raina, Chanda, Mehta, \& Maheshwari, 2003).

A common feature of strategy is its ability to initiate change in the organizational processes. In the case of turnaround strategy, while the circumstances leading to its adoption may be external, its focus is however on internal reorganization which pronounces itself to issues of organizational development and change programs. Organizations aim at transitioning from decline to a positive trend in performance which needs to be sustained. The achievements, experiences and lessons learned are considered as important part of breakthrough in performance which should be documented to form part of the mechanism enacted to hold the gains achieved as the firm aims at the target level of performances. Juran (1995) in his approach to addressing chronic problems accounting for poor performance suggests that in a process that aims to bring about breakthrough in the transition, there should be controls enacted to hold the gains. Such controls will need to be informed by the real life experience of the change experienced. Thus, in the pursuit of a strategy for turnaround due to the inherent aspect of change in the systems, there is need for a system to document the learned experiences.

This paper has been divided into four sections. The introductory section of the paper highlights the review of the publications that elaborate on the levels of strategies and the application of the strategies in pursuit of organizational change management. The literature review section presents a summary of the conceptual literature on the constructs of the study and theoretical literature on the theories upon which the study constructs are underpinned. The third section proposes the theoretical model and the propositions of the study. The final section of the paper details the study limitations, research implications and the authors' recommendations for further research.

\subsection{Statement of the Problem}

The extant literature on organizational development and change indicates that firms undergoing poor performance and the recovery strategies that are applied is a topic that is still understudied and therefore, little knowledge is available with respect to restoration of the health of the firms (Tenkasi \& Kamel, 2016). As scholars still have the task of understanding the insights of business failure, strategic change in the turnaround process indicates a gap that exists between corporate turnaround theory and the empirical findings (Barker III \& Duhaime, 1997). There is therefore need for clarity of the conceptualization of the subject of turnaround strategy and its influence on corporate performance. The concept needs a scholarly review in order to have conclusions on the effectiveness of different strategies that analyze both turnaround and non-turnaround firms.

The theoretical underpinning of research on turnaround is grounded on organization's change theory despite the lack of specific theories of the concepts exclusive to the respective topic (Schweizer \& Nienhaus, 2017). Although a collective knowledge regarding turnarounds has emerged over time, the management field's 
understanding of turnaround still remains immature and hence more theoretical propositions remain to be tested (Lohrke, Bedeian, \& Palmer, 2004, Trahms, Ndofor, \& Sirmon, 2013). Additionally, as much as there have been advances in the corporate turnaround studies, the empirical studies and methodologies for analyzing turnaround phases that determine the processes leading to successful turnarounds are still abstract in nature.

The acknowledgement of the fact that each turnaround situation is unique with respect to the individual firms calls for the appreciation that specific turnaround knowledge management skills and learned experiences pertaining to the situations need to be sought for. Corporate turnarounds are strategic management issues that involve strategic changes in the organizations. The concept needs to recognize the change management as a process for continuous monitoring in the direction, structure and capabilities of the firm so as to meet the strategic plans. The inadequate application of the relevant professional knowledge into the prevailing firm's circumstances have the effect of poor implementation of the strategies (Ayiecha \& Katuse , 2014). Given the prevailing circumstances of the subject, there is a call for identification of a model that links turnaround strategies and the requisite learned turnaround management experiences. The paper purposes to undertake a review of the extant conceptual, theoretical and empirical literature reviews so as to identify relationships and links between turnaround strategies and corporate performance with respect to the role of the learned experiences in turnaround management.

The paper seeks to address the following objectives; first, to undertake a comprehensive review of extant conceptual, theoretical and empirical literatures on turnaround strategies with a view to highlighting the phenomenon it brings about in organizations. Secondly, to identify conceptual, theoretical and empirical gaps with implications for assisting in further research and finally propose a theoretical model to respond to the gaps. The paper endeavors to contribute to strategic management body of knowledge by integrating the literature on turnaround with that on organizational change. Strategic turnaround literature is required so as to influence the practice of how pertinent organizational changes can be handled from the perspectives of corporate turnaround strategists. Secondly, based on the available theoretical and empirical literature, the paper gives an opportunity to consolidate the various existing knowledge in the discipline so as to enable the anchorage of such knowledge into relevant theoretical base. Thus, the researchers and theorists can be able to make conceptual, contextual and methodological analysis of the subject matter. Thirdly, the paper proposes away forward in the strategic management field that not only gives the conceptual strategic turnaround but also points the ultimate variables of operationalization in the context of the respective firms. Lastly, the proposed model provides an understanding of turnaround phenomenon together with all its components. This model further provides a new theoretical model and sets out the direction for future research.

The methodology adopted by the researchers to enable the achievement of the highlighted objectives and to respond to the scholarly calls is the wider review of the relevant empirical and theoretical literature in order to obtain a deeper understanding of the constructs. A conceptual review of the literature was done to enable the researchers get insights on the conceptualization of the constructs by scholars. A broad theoretical review was undertaken to provide the theoretical anchorage for the constructs whereas the empirical review established the nature of the constructs so as to appreciate the characteristics of the theories reviewed for the study.

\section{Review of Literature}

In order to enhance the understanding of the study objectives, the paper seeks to present a summary of the conceptual literature on the constructs of turnaround strategy, organizational turnaround-based learned experiences, organizational characteristics and corporate performance. This is then followed by a review of the relevant theories upon which the constructs are underpinned.

\subsection{Turnaround Strategy}

Organizational turnaround processes are primarily dedicated to company renewals. Turnaround management activities therefore revolve around review of management practices, activity-based costing and SWOT analysis to determine the main reasons for companies' failures (Thompson, Peteraf, Gamble, \& Strickland III, 2014). Turnaround strategies play critical roles that are concentrated in looking at the processes geared towards corporate renewals through analysis and planning mechanisms to return troubled firms to solvency and the strategies are often necessitated by the call to understand the circumstances that lead to corporate declines. Hence, the studies on firm turnarounds and causes of decline, management strategy challenges give the breakthrough point on the creation of body of knowledge and perspectives on turnaround strategies (Solnet, Paulsen, \& Cooper, 2010; Bibeault, Donald, 2017). Cultural and transformational changes during turnaround periods require management of the firms to prioritize the issues that can significantly improve the organizations (Johnson, Scholes, \& Whittington, 2005). The respective firms are bound to have a strategy that should describe 
the pursuit of goals by considering environmental threats and opportunities and the available resources and capabilities (Nandakumar, Ghobadian , \& O'Regan, 2010). As such, strategic management is directed towards analyzing, collating and overcoming the problems faced by the firms due to changes in the environment. Strategic management also examines the firm's rules that are set for decision making that guides organizational activities (Petrova, 2017).

Turnaround strategy can thus be looked at as the steps that are undertaken in order to enable a firm to move from financial declines and be able to meet the basic obligations to its business stakeholders (Hofer, 1980). Therefore, the strategy should address the issues of measurement and performance of a firm in order to appreciate its functionality and the process aims at achieving rapid performance within an acceptable time frame (Pandit, 2000, Slatter, Lovett, \& Barlow, 2006). What then emerges is the need to identify the appropriate set of applicable strategies under turnaround to raise the firm's performance to the desired levels of performance. We therefore suggest two aspects that emerge from the literature in connection with this desire, namely: identifying the applicable strategies under the turnaround option and the process of applying the turnaround strategies so as to raise and sustain performance at the desired level.

In terms of identifying the relevant set of strategies under a turnaround option, we identify two broad perspectives to classifying different types of turnaround strategies: Cost Based Approach and the 3Rs approach (Hofer, 1980, Boyne, 2004). The cost-based approach to turnaround strategy seeks to address improvement of performance or reversal of declining performance by cost cut backs, reducing the assets, increasing the revenues or a combination of efforts. The extant literature has indicated certain corporate turnaround strategies to primarily include cost reduction, asset reduction and restructuring as the common and popular strategies that the financially distressed firms employ. Cost reduction strategies involve the reduction in the firm's total costs including selling, general and administrative and interest costs. Asset retrenchment strategies involve net reductions in long- and short-term assets so that the firm has only adequate assets to operate with. Revenue generating strategies are undertaken by the firm through focusing on its existing lines of products, initiating price cuts and increasing marketing expenditures in order to stimulate demand (Hofer, 1980; Tikici et al, 2011).

The 3Rs approach to turnaround strategy on the other hand seeks to enhance the performance of the firm by internal realignments of the firm majorly through retrenchment, repositioning and reorganization. The proper timing of application of these strategies leads to the reversal of organizational decline and hence gives the firm the ability to attain a competitive advantage (Boyne, 2004). Retrenchment is a strategic response that considers reducing the scope and size of the firm. The major emphasis of the strategy is to ensure that there are cuts in the unproductive and unprofitable segments of the firm which in the long run releases available resources for investment in the segments considered potential for higher performance. Repositioning strategy considers growth and innovation of the firm by responding to the existing market demands and diversification into new markets and products. Reorganization strategies ensure efficiency that aims to make positive recovery and the strategies are categorised based on turnaround actions in terms of functional areas being addressed.

Faced with the two broad perspectives to turnaround, organizations have to make a choice on which specific strategy to adopt so as to offer an intervention suitable to reverse the declining trend in performance. From the reviewed literature, we are of the view that five types of strategies are suitable to operationalize a turnaround strategy: Cost reduction strategies, Revenue generation strategies, Asset retrenchment strategies, Repositioning strategies and Reorganization strategies. Cost reduction programs revolve around reduction on the firm's total cost which the management has to properly implement. Cost reduction strategy is achieved through reduction of existing expenses, elimination of non critical expenses and replacement of higher expenses. Revenue generating strategy encompasses the approaches undertaken by the management in order to enhance the firm's demand for the existing line of products. The approaches include the efforts achieved through price cuts, increased advertisments and direct sales of the products. Asset retrenchment that aims at ensuring there are cuts in the unproductive and unprofitable segments involve using the approach of reductions in size and scope of the firm. Repositioning strategy considers the firm's growth and innovation and is undertaken through diversification, product innovation and market penetration. Reorganization strategies are undertaken to enhance efficiency in the functional areas and are approached through planning systems changes, human resource strategies, decentralization strategies, production, technology strategies and financial restructuring.

An important aspect that needs attention in the choice of turnaround strategy is the need to provide an opportunity for the current conditions sustaining the declining trend to experience the impact of the components of the chosen strategy that are deployed in the form of an intervention. An intervention by its nature is a specific change methodology that unleashes the forces of change into a current state that is considered to be in a frozen state and unfreeze them towards a fluid state in which a transition can be experienced (Huse, 1980). As the 
system begins to change and embrace the components of the intervention, the system owners need to monitor the situation with a focus on identifying the nature of the change as the tansition begins and enact sufficient control mechanisms that can hold the gains in performance achieved or brought about by the applied strategy in the form of an intervention. In view of this, we see a closer link between the operation of a turnaround strategy and the experience of an organization going through a process of change for development and enhancement of organizational health (Bachmann, 2009). An important aspect of this experience of change is that arising from learning. In the context of turnaround strategies, managers need to integrate aspects of learning to facilitate development of mechanisms to capture and share learned experiences from the change being implemented.

The authors therefore propose that the constructs of the role of organizational learned turnaround experiences and organizational characteristics should be given due consideration for the purposes of understanding the choice of turnaround strategies and its linkage to corporate performance. The integrated study of these constructs therefore gives an opportunity to a significant knowledge of understanding organizational turnaround strategies and the subsequent enhancement of the subject and its conceptualization. To this end therefore, the paper will provide discussions on organizational turnaround-based learned experiences, organizational characteristics and corporate performance. It is notable that prevailing turnaround situations call for an understanding of how to handle and implement organizational development and change management. The evaluation of changes as a result of declines therefore necessitates that firms must develop and have experiences of turnaround knowledge which specifically assists in devising the turnaround strategies to implement. Firms have to invest in the acquisition of knowledge that specifically address the declining conditions and strategies that can be adopted in order to enhance relatively positive firm performance (Rothwell, Stavros, \& Sullivan, 2016). An understanding of organizational change process is pertinent in advancing the knowledge on how the firms adjust or fail to adjust to the new environmental conditions brought about by declines in business performances (Barker III, Vincent L.; Mone, Mark A.; 1998).

\subsection{Organizational Turnaround-Based Learned Experiences}

Turnaround strategy entails change within the organization under consideration. A critical factor in change programs is that of learning. If the systems sustaining declining performance are to produce better results, then there is need for change that is supported by a learning orientation suitable to enable process owners to keep track of gains being made in the transition brought about by the turnaround intervention. Learning in this context is described as the capacity of the organization to undergo through the three change stages of unfreezing, change and freezing processes (Lewin , 1947). Learning process ensures the acquisition of new knowledge and technological capabilities that enhance strategic decision making, tactical planning and operational activities of the firm (Trujillo, Baker, Parachinj, \& Chalk, 2005).

Corporate turnaround situations therefore require continuous learning and growth opportunities in order to ensure that relative performances are accounted for. Arguably, the notion of organizational learning provides the firm's management with various perspectives of the organization ranging from personal developments that are capable of increasing the firm's effectiveness (Senge P. M., 1990). The firm's effective training and development constitute one of the practices of successful organization. It is notable that, over the years, in-company development and management leadership has indicated significant growth that contributes to improved firm performance (Pedler, Burgoyne, \& Brook, 2005). Senge P.M (1990) defines organizational learning as the organizations in which people endeavor to expand the capacity to create desired results in which new and expansive patterns of thinking are nurtured. The basic rationale for organizational learning is to ensure that in the situations of rapid change, only those firms that are flexible, adaptive and productive would manage to excel. Hence, an organization that facilitates learning ensures its continuous transformation that leads to the achievement of its strategic goals (Pedler, Mike; Boydell, Tom; Burgoyne, John, 1989).

A number of dimensions distinguish the firm's learning that ensure that there is a convergence of innovation by the firm: These dimensions are: Systems thinking, Personal mastery, Mental models, Building shared vision and Team building. Systems thinking defines the conceptual cornerstone that integrates the organization's body of theory and practice. The systems thinking gives the conceptual framework that enables the study of businesses. An organization that has a continuous learning perspective uses systems thinking approach to assess the performance of its various components. Organizational systems thinking requires that all the organizational characteristics must be available at once within the organization so as to enhance a learning organization. Systems thinking therefore represents a framework adopted for organizational patterns and interrelationships (Yadav \& Agarwal, 2016).

Personal mastery defines the organization's ability to learn through its individuals. The dimension applies to the 
individual learning that ensures the organization's members learn before the organizational learning can be experienced. Personal mastery within the context of organizational learning defines the goals and the measures of the goals. It ensures that there are commitments for learning and hence forms part of the organizational learning (Dawoood, Mammona, Fahmeeda, \& Ahmed, 2015). Therefore, the organizations require personal mastery in order to achieve their strategic objectives. As popularized by Senge P.M (1990), the concept of organizational learning requires the presence of personal mastery in order to distinguish from others.

Mental models refer to the framework of cognitive individual processes and ensures the assumptions and generalizations are understood. The model enables the organizational staff to remain rational thinkers in order to evaluate whether organizational objectives are achieved. The assumptions that are in the possession of the organization and its staff ensure that the learning processes are challenged for the benefit of achieving the desired changes.

Building and development of the shared vision is considered important in the creation of a common identity that provides a focused learning through experimentation and innovation. The individuals within the organization have the capacity to share the ideas, proposals and visions that give diverse visionary aspects of the organizational operations. To enhance shared vision in the firms, learning organizations often have flat and decentralized structures which enhance the creation of vision through interactions with the organizational individuals (Senge P. M., 1990). Hence, organizational leadership plays a greater role of creating and sharing the organization's vision with the employees. Team building aspect of organizational learning enables the organizational members to be committed to the continual improvement of the firm's activities and goals. Team building enhances the process of aligning and developing the capacities of organizational team to create the firm's desired results. An organizational team is characterized by results driven structure, competence, commitment, collaboration and principled leadership with the eventual aim of achieving the organization's objectives.

Within the context of organizational change, learning is expected to play an important role in the process of change brought about by turnaround strategy. One of the approaches to change proposed by Kurt Lewin (1947) identifies three stages of the change process in which learning can be instrumental in addressing performance improvement from decline to recovery. As stipulated in the breakthrough sequence in addressing the firm's chronic financial problems, learning enables the firms to apply strategic control measures (Juran, 1995).

From the above discussion, an important nexus between turnaround strategies and the learning organization concept has been conceptually and theoretically demonstrated. This is an important observation in strategic management given that the scholarship has alluded to the role of learning during change in organizations without clear indications on how this learning may apply to different types of change programs and strategies. In the case of turnaround, the three stages from the planned change model by Lewin compare well to the situation faced by organizations undergoing decline calling for turnaround and clearly indicates how learning fits into the process in addressing the target of the strategy namely performance. Therefore, the firm's learned experiences with regard to turnaround situtations becomes imperative in the respective firm realignment process (Pillay, 2013). On the same breadth, the role of learned experiences with respect to firms in turnaround situations define the processes that enable turnaround specialists and managers to align applicable strategies, assimilate the situation then finally apply the strategies for the intended corporate results (Aurich, Fuchs, \& Wagenknecht, 2006).

\subsection{Organizational Characteristics}

Organizations are unique and demonstrate the same uniqueness in the manner they approach and apply different strategies. One way that has been used to measure and assess the effect of this uniqueness is that of organizational characteristics. Organizational characteristics are regarded as the firm's desired configurations that are defined by its management and aligned to its strategy or structure. The understanding of the concept of organizational characteristics is quite critical in the determination of the success of the turnaround strategies deployed by the firms (Watanabe \& Senoo, 2008). Organizational management of the turnaround situations therefore necessitates that there must be an efficient management structure that can ensure there are effective plans, controls and communication between the firm's stakeholders (Al-Turki, Duffuaa, \& Bendaya, 2019).

A number of components of organizational characteristics influence the adoption and implementation of turnaround strategies that eventually impact the extent of performance and results of turnaround candidate firms: These components are: Corporate governance systems, Firm size, Firm diversity and Organizational identity. Corporate governance systems ensure the desired company directives and decisions. Extant literature regards corporate governance arrangements in turnaround situations as being very imperative in the examination and achievement of the firm's objectives and corporate governance matters are supposed to take care of the industry 
dynamics and the stages of the firm's developments and growth to create strategic barriers in situations where the industry's fortune change (Filatotchev \& Toms, 2006). The development of governance capability is a determinant of turnaround and hence the changes in management that are incorporated into a declining firm are able to determine improvements as well as organizational capability that causes sustained firm performance (Harris, 1994). A merger of turnaround and corporate governance studies also highlight an evaluation of the role that the top governance of the firms can play in scenarios where they have to put to halt the firm's decline and subsequently reverse the declining performance (Lohrke, Bedeian, \& Palmer, 2004).This highlights that leadership is very essential for any firm decline or turnaround and the ability to obtain the required information that can be used to prompt an action and recommend corrective measures necessary for the firm's turnaround and sustainability (Ghazzawi, 2018).

Firm size stipulates the capability of the turnaround firms to undertake particular strategies. Firm size as a factor influences the ability of turnaround firms as they implement a number of turnaround strategies which ultimately affect turnaround performance (Schmitt \& Raisch, 2013). According to Barker III, Vincent L.; Mone, Mark A., (1998), there are indications that firm size influences the ability of the firm to change its strategic orientation based on the factors of complexity of the internal procedures, power structure extensions and existing relationship with external stakeholders that have the effect of blocking the firm's ability to bring changes that are anticipated. Studies by Abebe and Tangpong (2017) posit that firm's size as a control variable of the organization positively and significantly influence the relationship among turnaround firms with respect to turnaround practices involving lay offs, acquisitions and divestments whereas Pant (1991) notes that, size as one of the structural factors of the firm is a charactreristic that influences the organization's nature of competition in the industry and hence, determines the strategic implementation success.

Firm diversity domain influences the extent of organizational changes. The dimension is strongly associated with how the firm can be able to sell parts of the business or departments during financial crisis. Firm diversity takes various forms within the organization including the firm's demographics. Organizational identity on the other hand enhances human, financial and other critical resource success factors and the firm's identity during firm decline faces threats that can lead to misalignment with both the current and future competitive demands. This therefore calls for the management and turnaround consultants to undertake the key roles that ensure that firms revisit and revise the identity in order to support recovery (Rokwell, 2016). The uniqueness of the firm depicted through the organizational characteristics may be considered as a factor that conditions the firms manner of application of adopted strategies. There is therefore the requirement for the firm's understanding of the causes of decline in order to understand which particular strategies are applicable to tackle the decline.

\subsection{Corporate Performance}

Adoption and application of strategies has the main goal of addressing performance of an organization. The construct of performance is the main point of consideration leading to the adoption of turnaround strategies on the strength that the experienced declining trend in performance can be reversed for an upward trend. The most important role of corporate performance in the field of strategic management involves having a critical look at the conceptualization and measurement of business (Venkatraman \& Ramanujam, 1986). Hence, the firm's performance and specifically sustainable performance forms one of the critical objectives of all the organizations (Ritson, 2017). Over the years, measurement of firm performance has rather been a challenge to both scholars and business practitioners (Simerly \& Li, 2000).

Observations by Chakravarthy (1986) indicate that corporate performance is a multidimensional variable and hence applying a single index measure does not give a comprehensive analysis and understanding of the relationship of performance to the constructs being studied. It is therefore imperative to consider the use of multidimensional indicators to analyse firm performance. Thus, studies that consider performance as a dependent variable alternatively require to point out other variables that can give variations in firm performance.

Turnaround managers are therefore able to depict both financial and non-financial measures of performance to evaluate the effectiveness of turnaround strategies applied. To measure firm performance, financial measures applicable are gross profit, total organizational assets, revenue growth, earnings per share and return on investments. The Balanced Scorecard (BSC) provides a multidimensional tool for performance measurement that highlights a four pronged approach of performance as: financial, customer, internal business processes and learning and growth perspectives. The perspectives of the tool presents the indicators and are thereby able to assist in the translation of the firm's strategy into operational performance indicators (Kaplan \& Norton, 2001).

Corporate performance and the effectiveness of the firms are very critical for the management in both private and public institutions and in the conduct of organizational research practices. According to Morin and 
Audebrand (2014), management's efforts to maintain the firm's efficiency in terms of production, excellent and total quality management are all matters necessary for achieving organizational performance. In this respect, organizational performances are restricted to include financial, people and processes used to ensure the achievement of objectives and the environment in which the organizations evolve in. The firm's effectiveness can be categorised into the four distinct areas of systemic, social, technical and ecological. The systemic category signifies the sustainability of the firm through stability and growth; social component is related to worth of the company's personnel; technical component stresses on processes' efficiency and ecological component relates to the legitimacy of the organization.

Business performance therefore becomes the mechanism through which the firm undertakes an evaluation of all the efforts devoted to the achievement of business goals (Yildiz \& Karakas, 2012). The success of the firm is measured through its performance and is pegged on the achievement of its goals and objectives. Previously, accounting measures have been widely used to evaluate corporate performance (Brown \& Laverick, 1994; Abebe, Michael A., 2010; Schmitt \& Raisch, 2013; Nnabuife, Onwuka, \& Ojukwu, 2015). Therefore, organizational performance plays the critical roles of monitoring business progress and goals; monitoring the effective strategies as well as plans in order to ensure that the firm's implementation processes are controlled to support decision making for the firm's sustainable development and advancement.

On the other hand, other scholars have defined performance of firm through non-financial performance measures which incorporate the firm's awareness of its environment, maintenance of moral responsibility and recognition of employee relations. These measures are considered important in the control of organizational problems (Jacobs \& Kleiner, 1995, Cescon, 2015). Additionally, the appreciation of the role of non-financial measures of innovation and technological breakthroughs indicate the firm's intangible assets including knowledge are critical in enhancing the developmental and maintenance aspects of a firm's competitive advantage (Roberts, Neumann, \& Cauvin, 2017).

Broader dimensions of corporate performance have included measurements of performance in terms of firm position in the industry. Industry related measures of performance vary from: employment of product leadership strategies so as to increase value creation and desired firm performance (Zott \& Amit, 2008); cost leadership that the firm enhances through its experiences and investments in the production facilities, conservation and monitoring of the operating costs, thus leading to the achievement of cost leadership and the use of leverage of managerial efficiency (Valipour, Birjandi, \& Honarbakhsh, 2012); transformational leadership that determines the extent to which the firm's leadership can enable the employees to exploit the available business opportunities, lower costs and ultimately increased profitability; market driven leadership that makes use of low cost strategic processes more than competition to enhance firm performance and competitive advantage and level of market differentiation (Menguc, Auh, \& Shih, 2007; Matzler, Schwarz, Deutinger, \& Harms, 2008); innovation leadership that refers to the ability of the firm to use learning to produce its products and processes that differ from the competitors, thus contributing to the growth of firm performance (Menguc, Auh, \& Shih, 2007).

Schuster et al (1997) pointed out a different dimension of performance measurement that considers the behavioural aspects of the firm. Employee behavioural performance measures involve the organization's recognition of its employees when it has a carefully managed process that enables the participation and integration of its individuals and the organization so as to achieve productivity and gain competitive advantage. These behavioural aspects emanate from employee motivation; commitments that enable the achievement of performance through participation; innovation leadership through clarification of individual responsibilities and encouragement of individual initiatives; employee compensation that is an affairmative obligation of the firms to compensate the employees comensurate with their contributions to the firm's success (Schuster et al, 1997; Buren III, 2005; Carmeli, Gelbard, \& Gefen, 2010).

Corporate performance can be viewed in terms of the firm's readiness for change (Kontoghiorghes, Awbrey, \& Feurig, 2005; Kilika, 2012; Kimiti \& Kilika, 2018). Human resources and systems in the market environment can enhance organizational performance through consideration of organizational capacity to change. The firm's readiness for change determines the extent of the employees perception that the organization has the mechanisms that can enhance a successful change. The understanding of the firm's readiness for change is thus indicated by its dynamic capabilities through: organizational learning; innovation; adaptation through the ability to adjust and change that can be tested during the firm's financial distress in the economy; entrepreneurial standards in pursuit of growth and profitability (Smith, Hampson, Chaston, \& Badger, 2003; Rangarajan, Chonko, Jones, \& Roberts, 2004; Judge, Naoumova, \& Douglas, 2009).

A number of criteria establish firms as turnaround candidates and hence the firm's turnaround performance will 
be evaluated based on relative evaluation periods of time. Therefore, turnarounds are judged by improvements in performance indicated since measurements form an important dimension to stabilization of a declining organization (Khandwalla, 1983).

Based on the time frames for managing turnarounds, performance of the firms will be evaluated based on a number of variables. Return on investments is underscored as a primary performance variable in strategic research involving declines and turnarounds. Other variables of evaluating performance during turnarounds are measurements of change in net income, return on invested capital, return on assets, market share, stock market prices and sales growth.

Measurement of the impacts of turnaround strategy has conventionally focused on the cross-sectional analysis of firm performance. We however need an application of a longitudinal lense since the focus in a turnaround strategy is to reverse declining level of performance with a negative trend towards recovery changes gradually over time (Stritch, 2017). The longitudinal lense called upon may be justified along three considerations. First, tracking the change in performance over time will enable managers to better understand the manner in which the change brought about by the turnaround intervention is behaving over time. Secondly, adopting this lense offers an opportunity for management to effectively monitor the progress of the turnaround implementation so as to initiate contingency measures when the situation so demands. Thirdly, when viewed from the learning perspective, lessons learned from the effect of the strategy are better tracked in the course of implementation as opposed to the terminal stage so that the gains made are understood and the conditions accounting for such gains are given administrative support to ensure focus on the target is not lost. These agree with the implementation phases as expressed in Kurt Lewin's model of change. The model that involves the stages of unfreezing, change and finally refreezing is a recognized model that explains change implementation. To implement a change requires the organization's current state being changed to a desirable state which has to occur simultaneously (Hussain, et al., 2016) and making a decision as to what point at which to make steady the forces of change from any further impacts on organizational systems.

The differential performance derived from the turnaround strategy should therefore be analyzed based on the conceptual phases that a turnaround goes through. Hoffman R. C (1989) identified two phases of turnaround: downturn phase and upturn phase. The downturn phase refers to the first phase of financial downturn in which the firm's financial performance is considered to be below the expected norm for a period of time. This phase should be followed by an upturn phase in which the firm's financial performance should exceed the acceptable level for a period of time. Turnaround cycles are therefore determined by making comparisons of the change in the rates of growth in the organization's profitability to the industry's acceptable averages of prior performance, industry's profits and investments (Hoffman R. C., 1989). A stipulation posed by Pearce II and Robbins (1993) indicates the requirement that a firm is considered to have experienced a turnaround if its performance in both the downturn and upturn phases have changed greater than the industry's average.

Barker III, Vincent L.; Mone, Mark A.;, (1998) offered an alternative to the one based on phases and used the analysis of three consecutive years of declining return on the assets, occurring after a base year when the returns on assets were above the industry's average; the firm's performance low enough so as to cause losses; and the three years of decline followed by three years of an increase in returns on assets. Lastly, Schendel, Patton and Riggs (1976), analyze turnaround performance as being determined as a downturn phase of four years that have uninterrupted financial decline in the firm's net income followed by an upturn phase of four years that report an increase in net income that has an allowance of two year deviation in the downturn and upturn phases.

\subsection{Review of Supporting Theories}

The conceptual reviews have endeavored to give a comprehensive knowledge of understanding on the lead construct of turnaround strategy from its original background up to the point of possibility of a phenomenal growth into its subsequent deployment. It is hence pertinent to underpin such a phenomenal understanding on the appropriate theoretical grounding. Therefore, based on the conceptual review that has given rise to the above set of issues, there is need for the examination of theories that can explain the phenomenon brought about by application of turnaround strategy and its accompanying constructs. Since organizational turnaround research focusses on the issues of decline in firm's competitive advantage, going concern uncertainty, and the ultimate recovery of its competence, it becomes very prudent to have a consideration of the theories that investigate the competitive advantage sources and sustainability. A review of the theoretical literature interrogates the extant theoretical work so as to identify the relevant theories that scholars can use to better underpin and analyze the phenomenon arising from application of a turnaround strategy and the corresponding constructs. The theories identified to be relevant from a broad range of theoretical literature for discussion in this paper are: Stage Theory 
of Successful Turnaround, Structural Adaptation to Regain Fit Theory, The Resource Based View Theory, Contingency Theory and Learning Organization Theory.

\subsubsection{Stage Theory of Successful Turnaround}

The stage theory borrows its origins from Kurt Lewin's three stage model of freezing of the past events of the organization, moving to new information and refreezing through the processes of reinforcements and support for change (Lewin , 1947). Other scholars who also built on the stage theory were Alter and Hage (1993) while studying on the topic of organizations Working Together. Their study on the American business organizations was necessitated in order to improve the international competitiveness with emphasis on organizational form and cooperative linkages (Alter \& Hage, 1993). The use of stage theory involves categorization of the actions that lead to the poorly performing firm's eventual recovery or further decline. Hence, the theory is able to explain causes and the contexts of such eventualities. Corporate turnaround is never a static or single event since it is a situation that involves processes that are meant to define if there are improvements in firm performance on a relative time of consideration.

Stage theory becomes relevant in the studies of the subject due the fact that turnaround deals with reversal of the organizational performance and hence it becomes of considerable importance in understanding the growth of research on the decline of the organizations. The theory tends to be rooted in the concept of industrial economics and therefore explains the understanding of turnarounds with respect to statistical relationships and represents the available turnaround strategies that clarify performance and the influence of its contextual success factors (Chowdhury S. D., 2002). The main consideration for the application of stage theory is the fact that the theory enables an elucidation of the sequences of events of turnaround that culminates into the declining firm's eventual survival or failure. The authors are of the view that the stage theory underscores the assessment of how the different stages of turnaround strategy implementation leads to the eventual expected firm performance.

The theory is appropriate in the study of turnaround topics for two aspects: Turnaround involves a number of changes in the firm which are dynamic hence requiring the combination of processes over time; turnaround cases have different sequences in terms of implementation due to firm characteristics. It therefore argues that turnaround as a subject is based on the perspective of stage theory since the approach is able to explain the chronology of events that are helpful in the ultimate firm's survival or failure. The three critical requirements of the stage theory are identified as the incident, events and concepts and through such categorization, the model clarifies how the elements are relevant at each stage and can facilitate the progress of the firm's performance from deterioration to success or eventual decline (Chowdhury S. D., 2002).

\subsubsection{Structural Adaptation to Regain Fit Theory}

The structural adaptation to regain fit theory maintains that the firm's structure and any changes can be explained functionally by use of quantitative data by possibly making enquiries into the alignment of structure and strategy. A firm is said to be in a fit if its financial health indicates high performance which can translate to surplus funds that can be used for business expansions and diversification. Such expansions increase the size of business in order to create a misfit as compared to the firm's structure previously in use, hence leading to an adaptation of the structural change (Donaldson, 1987). The structural transformation of the firm is meant to enhance the generation of static and dynamic gains which translates into the productive transformation of processes. This follows theoretical work that structure will follow the strategy that has been laid down by the firm (Chandler, Jr., 1962).

The theory therefore becomes applicable in the understanding of turnaround management so that the management is able to concentrate on the recovery processes of the firm having in mind that the firms are not economically viable in their current fit situations and hence, calls for the firms to take advantage of the situation in order to enhance diversification, modernization and reorganizations that enables the firm's survival, continuity of operations, sustainable competitive advantage and performance. The theory is hence linked to the turnaround strategy that the firm employs in order to achieve its expected performance objectives. The authors therefore opine that the arguments brought about by the structural adaptation to regain fit theory are considerable for underpinning turnaround strategy construct and corporate performance that is brought about by the resulting adaptation of the identified strategies.

\subsubsection{Resource Based View Theory}

Resource Based View Theory can be traced back to the studies done by Penrose (1959). The theory is concerned with firm's resources management, firm production opportunities and strategies for diversification. The theory explains the logical links in the firm's resources and capabilities and the ultimate competitive advantage. The 
theory enables an understanding of the resources and how they can be productively invested in order to give rise to profitability and growth of the firm.

Barney J. (1991) underpins the concept of the RBV theory as the firm's resources that should be valuable, rare, imperfectly imitable and non-substitutable so that the application of the resources can result into a sustained competitive advantage. The theory considers the firm as a bundle of resources and hence it can be referred to as the theory of competitive advantage (Barney J. , 1991). The theory therefore becomes relevant in turnaround management studies so as to help the management in understanding how the organizations can be able to exploit the available resources and capabilities to counteract with the economic crisis dilemma. Hence, the resource-based view theory is linked to turnaround strategy and the firm's resources that are available to be used for the purposes of achieving the firm's expected performance. The authors have the view that the arguments brought about in the RBV theory are quite relevant to turnaround strategy construct and its subsequent implementation as a form of strategic choice. RBV considers the strategies adopted by declining firms as resources which the firms use to obtain value in line with the RBV's framework of VRION and the resulting organizational performance.

\subsubsection{Contingency Theory}

Contingency theory dates back to the works of Fiedler (1964) whose article concentrated on the contingency models and leadership. The theory explains the roles played by the organizational leaders with respect to their areas of operations. Contingency theory is considered to significantly enhance the understanding in strategic management research. According to strategic contingency theory, scholars argue that an effective strategy is dependent on the causes of the firm's decline (Trahms, Ndofor, \& Sirmon, 2013).

The determination of the causes of firm decline and the subsequent application of the contingency theory enables firm management and turnaround strategists to understand critically the appropriate turnaround strategies to employ and there is an ease of alignment between turnaround management strategies and performance of the firm (Wittig, 2017). Contingency theory therefore becomes very pertinent to the organizational managers as it gives a significant scope of decision making at the discretion of the firm. The theory is linked to turnaround strategies that are available to the declining firm by selecting those strategies that are contingent to the firm's businesses. The authors are of the view that the contingency theory is relevant in the study of turnaround strategy and firm performance as it provides a suitable framework for the study of organizational design by stating the best organizational structural design whose structure is able to align with organizational contingencies.

\subsubsection{Learning Organization Theory}

The theory dates back to the works of Senge P.M (1990) while exploring on the studies on the art and practice within the learning organizations. Learning organization concentrates on collecting and analyzing the individual and collective learning processes within the organizations. The process is injected in an organization in order to facilitate learning that can effectively assist the firm managers in the development of the firm's systemic and dynamic perspectives (Senge, Peter M.; Sterman, John D., 1992). The ultimate need of the learning is to ensure there is expansion of people's capacity in order to create the desired results (Garvin, 1993). To achieve the objective of organizational learning, there is need for use of five components: systems thinking, personal mastery, mental models, shared vision and team learning. Organizational learning is therefore a process that unfolds on a timely basis and henced linked to the acquisition of knowledge and improved firm performance (Senge P. M., 1990).

In order to achieve the firm's ultimate goal, learning organizations are built upon five major activities: systemic problem solving in which the firm relies on the scientific methods to solve firm problems, making use of data and using simple statistical tools for inferences; experimentation with new approaches through systemic searching and testing of new knowledge for ongoing and demonstration projects; learning from own experiences and past history in order to review successes and failures then making systemic assessments; learning from the experiences and best practices of others through the outside environment to gain new perspectives; and transferring knowledge quickly and efficiently throughout the organization (Garvin, 1993).

The theory becomes applicable in enhancing change management within the organization. The authors are of the opinion that for the organizational systems to sustain the decline in performance and realise better results, there is a critical requirement of a learning orientation that enables the management to track and monitor the results that accrue as a result of the turnaround interventions employed by the organization.

\section{Call for a Theoretical Model}

The reviewed literature on the subject of turnaround and the phenomenon it promises to bring about has implied 
pertinent issues that set the stage for further consideration in conceptualizing the role of turnaround strategy in a relevant firm strategic behavior. The emerging issues are therefore considered to be particularly important in the presentation and justification of a case for the model that advances new knowledge in strategic management discipline. According to Nachmias and Nachmias (2004), new knowledge advanced in both scholarly and scientific grounds requires a foundation upon which the knowledge can be supported. Therefore, in order to have a framework for the advancement of this knowledge, there is need to identify the constructs that underlie the phenomenon brought about by turnaround strategy in the life of an organization and their clear roles. Strategic management theories increasingly reflect on the organizational change whereas a number of empirical data have however indicated that there has been much preoccupation with designs of cross sectional data as opposed to the dynamic aspects of organizational strategy (Ginsberg, 1988).

The reviewed literature has explicitly revealed a clear understanding on the construct of turnaround strategy. The literature clearly brings out the nature and characteristics that enables an understanding of the construct. This understanding of the construct of turnaround strategy is explained by the various aspects that include diverse conceptualizations, definitions, components and perspectives that support the extraction of relevant indicators. From the literature, turnaround strategy can be operationalized through five major indicators: cost reduction strategy, revenue generation strategy, asset retrenchment strategy, repositioning strategy and reorganization strategy (Hofer, 1980; Sudarsanam \& Lai, 2001; Boyne, 2004; Tikici et al, 2011).

Based on the forgoing argument, the authors identify the possibility of an emerging phenomenon that arises from the adoption of turnaround strategy in firms as a strategic option. The emerging phenomenon can be looked at in two perspectives: the potential that the organization gains by the turnaround strategy and the context in which the strategic option is optimized. The potential the turnaround strategy injects in the organizational system and the turnaround management capacity which when combined with the strategic resources lead to the attainment of an organization's sustainable competitive advantage. Competitive advantage of the firm is reflected through both financial and non-financial dimensions of firm performance. Financial dimensions include gross profit, return on assets, revenue growth, earnings per share and return on investment (Kaplan \& Norton, 2001). Non-financial dimensions include operational efficiency, total quality management, labor productivity, lead times and product defects depicted through the industry related performance measures, employee performance measures and readiness for change measures. Contextually, strategic option of turnaround strategy is built by considering all the relevant factors of market and competitive environment, strategic change, business constraints and management commitments. As argued in the corporate performance construct, the construct is the ultimate state whose attainment is preceded by the antecedent construct of turnaround strategy, the intermediate construct of organizational learning and the contingent variable of organizational characteristics.

We derive support from the above logic not only from the theoretical and conceptual literature but also from the extant empirical work. The above possibility is evidenced in a number of empirical studies reviewed. The authors have noted the possible relationships between turnaround strategy and other variables that give rise to implication for future research. A number of empirical studies analyzed the relationship between turnaround strategy and corporate performance. Examples include the following; Kazozcu (2011) investigated the role of strategic flexibility in the choice of turnaround strategies in Turkey and established the positive relationships between firm resources and performance. Wandera, Sakwa and Mugambi (2017) assessed the relationship between cost strategies and performance of state-owned sugar companies in Kenya and established the positive relationship between turnaround strategies and organizational performance. Ukaidi (2016) while exploring the impact of turnaround strategy and corporate performance among the quoted companies in Nigeria established that performance is attributed to turnaround strategy as a management tool. On the assessment of turnaround strategy on the organizational performance of industrial estates in Kenya, Wanyonyi and Nyakweba (2016) concluded that turnaround strategies entail organizational streamlining that enable a firm to improve its performance. Sudarsanam and Lai (2001) conducted a study on corporate financial distress and turnaround strategies of various bankrupt firms in the United Kingdom concluding that the selection of corporate turnaround strategies requires swift managerial actions in order to enhance performance.

The support for a phenomenon based on empirical work is further strengthened by consideration of relevant studies that have attempted to show how theories underpinning the constructs in the identified phenomenon have been applied in those studies. A number of empirical studies of the respective constructs have employed the use of the theories to explain their relevance and important roles in strategic management research. Studies by Wanyonyi and Nyakweba (2016), Panicker and Manimala (2015) applied the use of Stage theory of successful turnaround to undertake an assessment of the influence of turnaround strategy on firm performance and to compare causes of organizational decline and turnaround strategies involved in the cases of successful and 
unsuccessful turnarounds respectively. Scholarly studies by Wandera, Sakwa and Mugambi (2017) used Structural Adaptation to Regain Fit theory to make an assessment of the relationship between cost reduction strategies and organizational performance. Studies by Hofer (1980), Kazozcu (2011), Hoffman, Hoelscher , and Sherif (2005), Machuki, Aosa and Letting (2012) and Pires and Trez (2018) respectively applied the use of Resource Based View theory to describe the framework for the firm's strategies and its strategic business units, analyze key firm resources and strategic flexibility and choice on turnaround situations, examination of how knowledge management affects the performance of the organizations, influences of firm level institutions on performance and corporate reputation in relation to performance. Studies by Barker and Mone (1994), Schoenberg, Collier, and Bowman (2013) and Ukaidi (2016) respectively applied the use of Contingency theory to analyze retrenchment as a consequence of steep performance, analysis of both content and process-oriented turnaround strategies and the contextual factors of turnaround strategies and performance.

As a result of the emerging phenomenon, we identify the need for expressing the phenomenon in form of a theory through a theoretical model that provides a clear understanding of the constructs. From an epistemological perspective, the theoretical model is necessary as it concerns what constitutes the acceptable knowledge in that field that is being studied (Nachmias \& Nachmias, 2004). Research studies involve the use of both inductive and deductive approaches for logical reasoning. Inductive approach involves a plan to explore the research data in order to develop theories that subsequently relates to the literature. This approach implies that research cannot be possibly taken without a competent knowledge of the subject area. On the other hand, deductive approach involves the use of literature to help in the identification of theories and ideas that are used to test the research data (Saunders, Lewis, \& Thornhill, 2009).

The logic of deductive reasoning is applicable in the call for the theoretical model since the deductive logic is a top down approach in which a theory on the topic of interest is developed, then the researcher specifies the hypotheses that can be empirically tested (Trochim, 2006). The deductive approach enhances the explanation of the causal relationships between the variables of study and enables the researcher to have the concepts operationalized in a manner that allows the quantitative measure of facts (Trochim, 2006). According to Nachmias and Nachmias (2004), in research settings, the ideas and theories are meant to be formulated first before the empirical research, what has commonly been referred to as the theory-before-research model. Therefore, to understand the theoretical framework, the researcher follows the progression of ideas, theories, designs, data collection, analysis and findings (Bruce, 2001). Additionaly, according to Johansson (2004), the theories can be categorized according to their scope, functions, structure and levels, whereas the model that refers to the abstraction from the reality is supposed to serve the duty of ordering and simplifying the view of the reality by representing the essential characteristics.

\subsection{Proposed Theoretical Model}

In response to the issues identified in the literature depicting both the richness of the extant theoretical, conceptual and empirical multidisciplinary literature and the inherent set of knowledge gaps, the authors undertake to extend this level of scholarship to new frontiers by proposing a new conceptual model. The suggested theoretical framework model presents the phenomenon derived from the application of a turnaround strategy in a manner that shapes firm strategic behavior. In this behavior, the phenomenon entails other constructs that draw from its conceptual analysis as well as those that derive from the strategic management characteristic of strategic thinking where internal and external contexts emerge for consideration. Several constructs that play different roles in the phenomenon emerge and have been used to inform the model as summarized in figure 1.

The antecedent factor is turnaround strategy in the proposed theoretical model. The ultimate factor is corporate performance whose realization is preceded by both the antecedent and intermediate factors. Organizational learned experiences serve as the intermediate factor in the theoretical model whereas the contingent factor in the model is the organizational characteristics. 


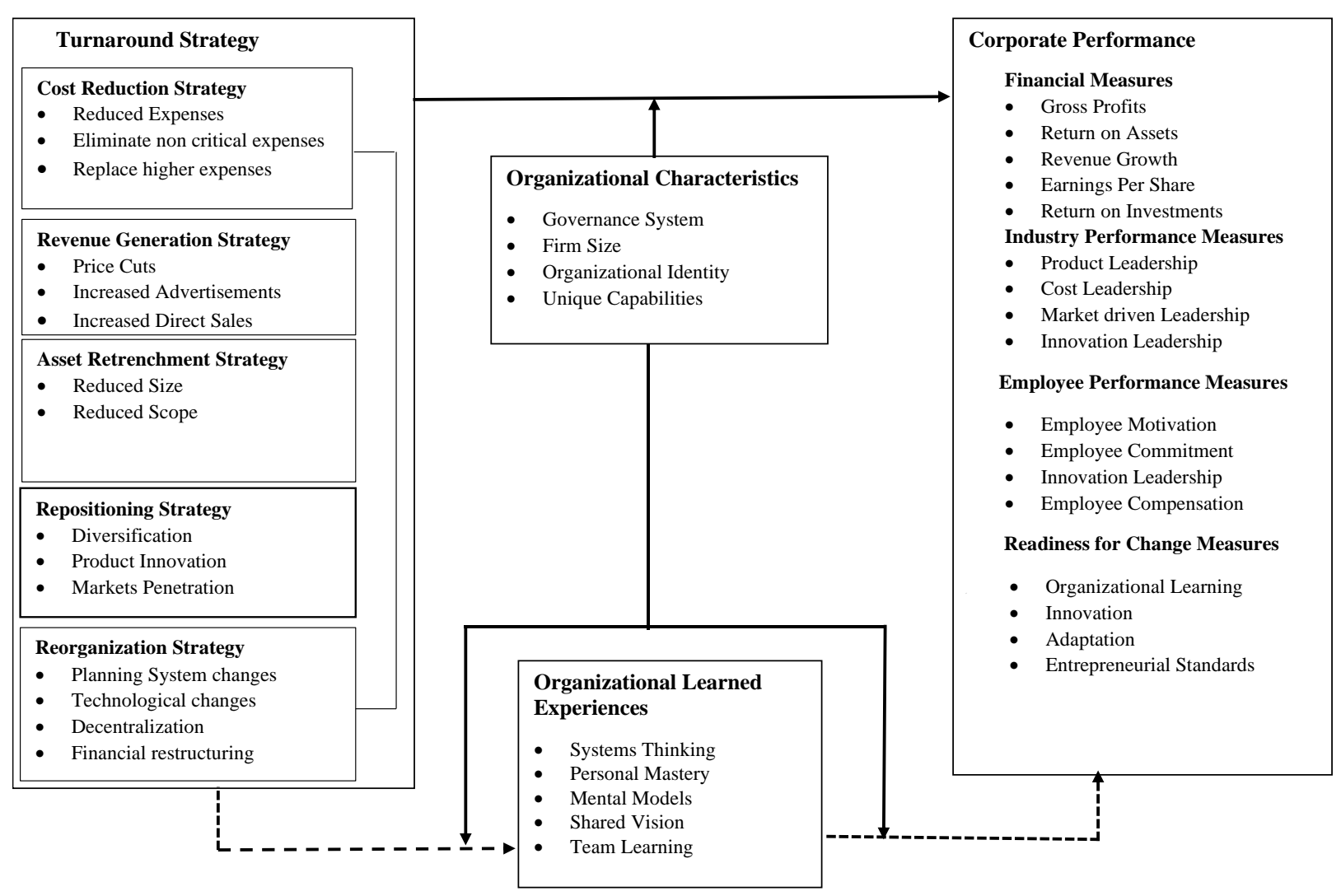

Figure 1. Theoretical Model Linking Turnaround Strategy and Corporate Performance Source: (Author 2019)

\subsection{Turnaround Strategy and Corporate Performance}

The proposed phenomenon is initiated by the deployment of turnaround strategy as the antecedent factor. Turnaround strategies as stipulated by Nandakumar, Ghobadian and O'Regan (2010), are derived from corporate levels that are adopted by the organizations in order to attain development, stabilization and survival during periods of financial distress. The construct is operationalized such that its deployment brings into the firms the multifunctional performance effects.

The firm's adaptation to its strategies and structures is considered very critical when there are changes in the business environment that require a strategic capability to enable an organization to align itself to the change at an appropriate speed. Turnaround strategies are therefore very essential for strategic transformation for competitive efficiency and effectiveness. The reform programs for firms in financial declines employ the specific strategies that are capable of ensuring the firm improves its performance. These strategic measures are meant to avail conducive internal and external business environments which are adaptable to the firms. Therefore, the firm's success or further failure is dependent on its ability to adapt to the transition processes available for implementation (Solnet, Paulsen, \& Cooper, 2010).

Turnaround strategy has been operationalized through cost reduction strategy, revenue generation strategy, asset retrenchment strategy, repositioning strategy and reorganization strategy. Corporate performance construct has conventionally been measured by use of accounting and financial measures. However, broader dimensions owing to the application of diverse turnaround strategies create other performance measures over and above the financial parameters. Such measures include dimensions of organizational well-being in terms of industry related measures, employee centered measures and the organization's readiness for change (Schuster et al, 1997; Smith et al, 2003; Rangarajan et al, 2004; Zott \& Amit, 2008; Judge, Naoumova, \& Douglas, 2009).

The application of turnaround strategy therefore serves the purpose that is focused on the achievement of the desired firm performance through implementation of its corporate strategies. Given that the application of 
turnaround strategies are meant to enhance the firm's cultural and transformational changes during turnaround periods, the strategies require the management's prioritization of issues that improve the organization's performances particularly through the steps undertaken to enable the firm to move from financial declines to meet the basic obligations of business stakeholders (Hofer, 1980; Johnson, Scholes, \& Whittington, 2005). The analysis of the link between turnaround strategy and corporate performance thus leads to the proposition that:

Proposition 1: The application of diverse turnaround strategies by a firm in financial decline will positively influence the achievement of various dimensions of corporate performance.

\subsection{The Role of Organizational Turnaround-Based Learned Experiences}

The firm's turnaround systems that sustain the performance are supported by a learning orientation that is suitable to enable the process owners to keep all the tracks of gains that are made in the transition through turnaround intervention. The firm's awareness is critical in the management of turnaround strategies that ensure the promotion of actions leading to the reversal of firm decline. Therefore, the management has to be in possession of an adaptive learning in order to identify the firm's causes of decline and recommend the necessary corrective measures (Ghazzawi, 2018). Turnaround process therefore requires swift actions of the management that are achieved through an adaptive learning by the firm (Sudarsanam \& Lai, 2001). Learning processes serve the purpose that leads to the acquisition of new knowledge and technical capabilities enhancing strategic decision making, tactical planning as well as operational activities (Trujillo et al, 2005). The in - company development and management leadership are meant to enhance growth that contribute to improved firm performance (Pedler, Burgoyne, \& Brook, 2005).

Organizations facilitating learning therefore ensure there is a continuous transformation that leads to the achievement of their strategic goals (Pedler, Mike; Boydell, Tom; Burgoyne, John, 1989). This is in support of the fact that the corrective actions the firm management employs during turnaround situations are inherently dependent on how well the management understands the requisite information concerning the causes of decline since the measures are contingent upon the causes of decline. To this extent therefore, the organization's turnaround based learned experiences in managing turnaround strategies are very appropriate in the achievement of the organizational performance objective. As argued by Trahms, Ndofor and Sirmon (2013), management's accurate perception of the firm's downturn is essential since any poor assessement of the situations are highly likely to result in ineffective firm restructuring strategies. Therefore, the firm's awareness and detection, recognition and acceptance, knowledge, attribution to the causes of decline and adaptive learning are very critical steps that aid the management in dealing with the turnaround situations. It is in this respect that the organization's turnaround based learned experiences with regard to turnaround situations are imperative in the respective firm realignment process (Pillay, 2013). This therefore leads to the propositions:

Proposition 2a: There is a correlation between the deployed turnaround strategies and the organizational learned experiences

Proposition 2b: The organization's learned experiences mediate the relationship between the deployment of turnaround strategies and corporate performance.

\subsection{Organizational Characteristics}

Organizational characteristics are critical in the success of turnaround strategies that are deployed by the firms in order to improve financial performance. Firm improvement needs the presence of an efficient management structure that ensures effective plans, controls and communication between the relevant stakeholders (Watanabe \& Senoo, 2008; Al-Turki, Duffuaa, \& Bendaya, 2019). Various components of organizational characteristics have influence on the relationship between turnaround strategies and corporate performance. The size of the company is potentially an exploratory determinant of the leverage differences among the firms in an industry. Firm size as a factor is very critical in the evaluation of performance owing to the economies of scale phenomenon, meaning, relatively firms can obtain cost leadership depending on the sizes that subsequently become a resource in terms of acquiring sustainable competitive advantage with respect to profits and market shares. Large firm size has the effect of restricted ability to change the strategic orientation due to robust internal control systems, stringent organizational structures that may inhibit the required firm changes. As pointed out in the resource-based theory, large structured firms may have the advantage to undertake a number of strategies due to the leverage factors hence have the ability to face numerous economic adverse factors (Barker III, Vincent L.; Mone, Mark A.;, 1998; Francis \& Desai, 2005).

Corporate governance systems and practices have the link to corporate efficiencies as they determine the efficiency and performance of the organizations with reference to the returns on equity. The systems are 
imperative in the examination of the substantial barriers during the periods of industrial change. The organization's governance is charged with an assessment of the firm decline and its causes and thereby formulating the specific strategies that can trigger the performance of the firm. Governance role ensures an implementation of the necessary decisions for recovery and failure to manage the turnaround process would give rise to continual decline and eventual economic failure and bankruptcy of the firms. A number of organizational turnaround experts examine corporate governance replacement as being a critical ingredient for any business recovery (Filatotchev \& Toms, 2006; Chen \& Hambrick , 2012; Ghazzawi, 2018). Additionally, organization's identity is critical in the choice of turnaround to the extent of enhancing human, financial and critical resource success factors that are capable of supporting the organizational financial recovery (Rokwell, 2016). At the performance level, there is need for enhancing the congruence that exist between organizational characteristic level and the role of organizational learned experiences towards the implementation of turnaround strategies. Firm management have the responsibility of identifying the correlation between the available turnaround resources and the implementation management experiences. This has the implication for the management in the application and adjustment of the strategies accordingly. Based on the above argument and congruence of the constructs, we propose that:

Proposition 3a: Organizational characteristics determine the choice of firm turnaround strategies and eventual performance.

Proposition 3b: The relationship between the deployed turnaround strategies and corporate performance is moderated by organizational characteristics.

Proposition 3c: The mediated effect of organizational learned experiences on the relationship between turnaround strategies and corporate performance will be moderated by organizational performance

\section{Study Limitations}

Despite the clear understanding of the constructs, there are limitations that exist in regard to corporate performance construct with respect to the nature of application of turnaround strategies and the need for expansion of the scope of the indicators of corporate performance. The study has not made use of the empirical data that can be tested in order to make conclusive propositions on the relationships existing among the constructs of the study.

\subsection{Recommendations and Further Research}

Based on the dilemmas in the empirical work and inconclusive findings brought about by the limitations in conceptual and theoretical literature, the paper has identified the emerging gaps that have been used to propose a theoretical model to address the gaps for use in further scholarship. The proposed model gives a comprehensive attempt to understand the phenomenon arising from the application of turnaround strategies, the intermediate and ultimate results of corporate performance and the contingent factors that condition the phenomenon.

Based on the foregoing, the authors are of the opinion that the proposed theoretical framework can be used as a suitable basis for future research based on the given constructs, indicators and the direction of the relationships via the set propositions. The future work will require the development of measurement parameters and contexts for undertaking the studies so as to move from the abstract state of this study to an empirical state. The authors take note of the lack of empirical data that can be tested in order to support the given propositions as limitations which further scholarship work can overcome through developing measurement parameters and finally employing such measures to use in the collection of primary data and setting up the statistical techniques that can be used for hypothesis testing.

\subsection{Conclusions}

The purpose of the paper was to look at the nature of turnaround strategy construct and distil the features of the phenomenon that are brought about in the firm's strategic management. The construct has its place in strategic management by the virtue of being a strategy developed at the organization's corporate level. The organization has to perform a SWOT analysis in order to identify the gaps that require immediate and strategic responses. Therefore, the manner in which the gaps are responded to form the dimension of turnaround strategies. The deployment of the turnaround strategies in the organizational setting leads to the desired performance which is mediated by the organizational turnaround based learned experiences and conditioned by the organizational characteristics.

The paper presented the conceptual understanding of each construct through the identification of operational indicators as well as identifying the theories underpinning each of the constructs on the theoretical framework derived from Stage Theory of Successful Turnaround, Structural Adaptation to Regain Fit Theory, The Resource 
Based View Theory, Contingency Theory and Learning Organization Theory. The paper highlighted the areas where the theories that underpin the constructs are complementary as well as the description of the strategic behavior of the constructs.

\section{References}

Abebe, M. A., \& Tangpong, C. (2017). Founder -CEOs and Corporate turnaround among declining firms. Corporate Governance: An International Review, 26, 45-57. https://doi.org/10.1111/corg.12216

Abebe, M. A. (2010). Top team Composition and corporate turnaround under environmental stability and turbulence. Leadership \& Organizational Development Journal, 31(3), 196-212. https://doi.org/10.1108/01437731011039325

Alter, C., \& Hage, J. (1993). Organizations Working Together. Newbury Park, CA: Sage.

Al-Turki, U., Duffuaa, S., \& Bendaya, M. (2019). Trends in turnaround maintenance planning: literature review. Journal of Quality in Maintenance Engineering. https://doi.org/10.1108/JQME-10-2017-0074

Aurich, J. C., Fuchs, C., \& Wagenknecht, C. (2006). Life cycle oriented design of technical Product-Service Systems. Journal of Cleaner Production, 14, 1480-1494. https://doi.org/10.1016/j.jclepro.2006.01.019

Ayiecha, F. O., \& Katuse, P. (2014). Implementing Turnaround Strategy:Effect Of Change Management Competence Factors. Journal of Business and Management, 16(3), 95-103. https://doi.org/10.9790/487X-163595103

Bachmann, C. (2009). Sustainable performance increase and strategic turnaround management: current corporate restructuring experiences in the Romanian market. Business Strategy Series, 10(6), 331-338. https://doi.org/10.1108/17515630911005600

Barker III, V. L., \& Mone, M. A. (1994). Retrenchment:Cause of Turnaround or Consequence of Decline? Strategic Management Journal, 15(5), 395-405. https://doi.org/10.1002/smj.4250150506

Barker III, V. L., \& Duhaime, I. M. (1997). Strategic Change in the Turnaround Process: Theory and Empirical Evidence. Strategic Management Journal, 18, 13-38. https://doi.org/10.1002/(SICI)1097-0266(199701)18:1<13::AID-SMJ843>3.0.CO;2-X

Barker, I. V. L., \& Mone, M. A. (1998). The Mechanistic Structure Shift and Strategic Reorientation in Declining Firms Attempting Turnarounds. Human Relations, 51(10), 1227-1258. https://doi.org/10.1177/001872679805101002

Barney, J. (1991). Firm Resources and Sustained Competitive Advatage. Journal of Management, 7(1), 99-120. https://doi.org/10.1177/014920639101700108

Bibeault, D. (2017). Turnaround Strategies Practical Insights From a 47 - Year Career. In J. Adriaanse, \& J. P. Rest (Eds.), Turnaround Management and Bankruptcy. Routledge. https://doi.org/10.4324/9781315738116-8

Boyne, G. A. (2004). A '3Rs' Strategy for Public Service Turnaround: Retrenchment, Repositioning and Reorganization. Public Money \& Management, 24(2), 97-103. https://doi.org/10.1111/j.1467-9302.2004.00401.x

Brown, D. M., \& Laverick, S. (1994). Measuring Corporate Performance . Long Range Planning, 27(4), 89-98. https://doi.org/10.1016/0024-6301(94)90059-0

Bruce, L. B. (2001). Qualitative Research Methods for the Social Sciences (4th ed.). Pearson Education Company.

Buren, I. H. J. (2005). An Employee-Centered Model of Corporate Social Performance. Business Ethics Quarterly, 687-709. https://doi.org/10.5840/beq200515447

Carmeli, A., Gelbard, R., \& Gefen, D. (2010). The importance of innovation leadership in cultivating strategic fit and enhancing firm performance. The Leadership Quarterly, 21, 339-349. https://doi.org/10.1016/j.leaqua.2010.03.001

Cescon, F. (2015). The Impact of AMT Firm Characteristics on Innovative Costing Techniques and Non-Financial Measures of Performance. In Performance Measurement and Management Control: Global Issues, 91-115. https://doi.org/10.1108/S1479-3512(2012)0000025007

Chakravarthy, B. S. (1986). Measuring Strategic Performance. Strategic Management Journal, 7, 437-458. https://doi.org/10.1002/smj.4250070505 
Chandler, J. A. D. (1962). Strategy and Structure: Chapters in the History of the Industrial Enterprise. University of Illinois at Urbana-Champaign's Academy for Entrepreneurial Leadership Historical Research Reference in Entrepreneurship. Retrieved from https://ssrn.com/abstract=1496188

Chen, G., \& Hambrick , D. C. (2012). CEO Replacement in Turnaround Situations: Executive (Mis) Fit and Its Performance Implications. Organization Science, 23(1), 225-243. https://doi.org/10.1287/orsc.1100.0629

Chowdhury, S. D. (2002). Turnarounds: A Stage Theory Perspective. Canadian Journal of Administrative Sciences, 19(3), 249-266. https://doi.org/10.1111/j.1936-4490.2002.tb00271.x

Dawoood, S., Mammona, F., \& Ahmed, A. (2015). Learning Organization-Conceptual and Theoretical Overview. International Journal of Humanities Social Sciences and Education (IJHSSE), 2(4), 93-98.

Donaldson, L. (1987). Strategy and Structural Adjustment to Regain Fit and Performance: In Defence of Contingency Theory. Journal of Management Studies, 1-24. https://doi.org/10.1111/j.1467-6486.1987.tb00444.x

Fadun, S. O. (2014). Strategic Management, an Organisational Risk Management Framework: Case Study of Guaranty Trust Bank Plc. International Journal of Academic Research in Accounting, Finance and Management Sciences, 4(2), 51-61.

Fiedler, F. E. (1964). A Contingency Model of Leadership Effectiveness. Advances in Experimental Social Psychology, 149-190. https://doi.org/10.1016/S0065-2601(08)60051-9

Filatotchev, I., \& Toms, S. (2006). Corporate Governance and Financial Constraints on Strategic Turnarounds. Journal of Management Studies, 43(3), 407-433. https://doi.org/10.1111/j.1467-6486.2006.00596.x

Finerty, T. (2014). Rapid Strategy Deployment - aligning the organisation around strategy. ResearchGate, 1-7.

Francis, J. D., \& Desai, A. B. (2005). Situational and organizational determinants of turnaround. Management Decision, 43(9), 1203-1224. https://doi.org/10.1108/00251740510626272

Garvin, D. A. (1993). Performance Review: Building a Learning Organization. Harvard Business Review, 65-140.

Ghazzawi, I. A. (2018). Organizational Turnaround: A conceptual Framework and Research Agenda. American Journal of Management, 17(7), 10-24. https://doi.org/10.33423/ajm.v17i7.1698

Ginsberg, A. (1988). Measuring and Modelling Changes in Strategy: Theoretical Foundations and Empirical Directions. Strategic Management Journal, 9, 559-575. https://doi.org/10.1002/smj.4250090604

Harris, S. (1994). Questioning the established wisdom in turnaround management. Journal of Strategic Change, 3, 211-225. https://doi.org/10.1002/jsc.4240030405

Hofer, C. W. (1980). Turnaround Strategies. Journal of Business Strategy, 1(1), 19-31. https://doi.org/10.1108/eb038886

Hoffman, J. J., Hoelscher, M. L., \& Sherif, K. (2005). Social capital, knowledge management, and sustained superior performance. Journal of Knowledge Management, 9(3), 93-100. https://doi.org/10.1108/13673270510602791

Hoffman, R. C. (1989). Strategies for corporate turnarounds: what do we know about them? Journal of General Management, 14(3), 46-66. https://doi.org/10.1177/030630708901400304

Huse, E. (1980). Organizational Development and Change. St. Paul Minn. West Publ. Co.

Hussain, S. T., Lei, S., Akram, T., Haider, M. J., Hussain, S. H., \& Ali, M. (2016). Kurt Lewin's change model: A critical review of the role of leadership and employee involvement in organizational change. Journal of Innovation \& Knowledge, 123-127. https://doi.org/10.1016/j.jik.2016.07.002

Jacobs, W. L., \& Kleiner, B. H. (1995). New Developments in Measuring Corporate Performance. Management Research News, 18(3/4/5), 70-77. https://doi.org/10.1108/eb028407

Johansson, R. (2004). Theory of Science and Research Methodology. Stockholm: Royal Institute of Technology.

Johnson, G., Scholes, K., \& Whittington, R. (2005). Exploring Corporate Strategy. Edinburgh Gate: Prentice Hall.

Judge, W. Q., Naoumova, I., \& Douglas, T. (2009). Organizational capacity for change and firm performance in a transition economy. The International Journal of Human Resource Management, 20(8), 1737-1752. https://doi.org/10.1080/09585190903087107 
Juran, J. M. (1995). Managerial Breakthrough: The Classic Book on Improving Management Performance. McGraw-Hill Education.

Kaplan, R. S., \& Norton, D. P. (2001). Transforming the Balanced Scorecard from Performance Measurement to Strategic Management: Part II. American Accounting Association, 15(2), 147-160. https://doi.org/10.2308/acch.2001.15.2.147

Kazozcu, S. B. (2011). Role of Strategic flexibility in the choice of turnaround strategies: A resource based approach. Procedia Social and Behavioral Sciences, 24, 444-459. https://doi.org/10.1016/j.sbspro.2011.09.039

Khandwalla, P. N. (1983). Turnaround management of mismanaged complex organizations. International Studies of Management \& Organization, 13(4), 5-41. Retrieved from https://www.jstor.org/stable/40396962

Kilika, J. M. (2012). Insititutional Context, Collaboration, Human Resource Development Infrastructure and Performance of Universities in Kenya (Unpublished PhD Thesis). School of Business, University of Nairobi.

Kimiti, P. G., \& Kilika, J. M. (2018). Organizational Resources, Industry Velocity, Attention Focus and Firm's Performance: A Review of Literature. International Journal of Business and Management, 13(5), 185-200. https://doi.org/10.5539/ijbm.v13n5p185

Kontoghiorghes, C., Awbrey, S. M., \& Feurig, P. L. (2005). Examining the Relationship Between Learning Organization Characteristics and Change Adaptation, Innovation, and Organizational Performance. Human Resource Development Quarterly, 16(2), 185-211. https://doi.org/10.1002/hrdq.1133

Lewin, K. (1947). Frontiers in Group Dynamics: Concept, Method and Reality in Social Science; Social Equilibria and Social Change. Human Relations, 1(1), 5-41. https://doi.org/10.1080/00208825.1983.11656375

Lohrke, F. T., Bedeian, A. G., \& Palmer, T. B. (2004). The role of top management in formulating and implementing turnaround strategies: a review and research agenda. International Journal of Management Review, 5/6(2), 63-90. https://doi.org/10.1111/j.1460-8545.2004.00097.x

Machuki, V. N., Aosa, E. O., \& Letting, N. K. (2012). Firm-Level Institutions and Performance of Publicly Quoted Companies in Kenya. International Journal of Humanities and Social Science, 2(21), 298-312.

Matzler, K., Schwarz, E., Deutinger, N., \& Harms, R. (2008). The Relationship between Transformational Leadership, Product Innovation and Performancein SMEs. Journal of Small Business \& Entrepreneurship, 21(2), 139-151. https://doi.org/10.1080/08276331.2008.10593418

Menguc, B., Auh, S., \& Shih, E. (2007). Transformational leadership and market orientation: Implications for the implementation of competitive strategies and business unit performance. Journal of Business Research, 60, 314-321. https://doi.org/10.1016/j.jbusres.2006.12.008

Morin, E. M., \& Audebrand, L. K. (2014). Organizational Performance and Meaning of Work: Correcting for Restricted Range. ResearchGate, 1-18. Retrieved from https://www.researchgate.net/publication/228938395

Morrow, J. J. L., Sirmon, D. G., Hitt, M. A., \& Holcomb, T. R. (2007). Creating Value in the Face of Declining Performamnce: Firm Strategies and Organizational Recovery. Strategic Management Journal, 28, 271-283. https://doi.org/10.1002/smj.579

Nachmias, C., \& Nachmias, D. (2004). Research Methods in the Social Sciences (5th ed.). London: Arnold.

Nandakumar, M., Ghobadian, A., \& O'Regan, N. (2010). Business Level Strategies and Performance: The Moderating effects of environment and structure. Management Decision, 48(6), 907-939. https://doi.org/10.1108/00251741011053460

Nnabuife, E. K., Onwuka, E. M., \& Ojukwu, H. S. (2015). Knowledge Management and Organizational Performance in Selected Commercial Banks in Awka, Anambra State, Nigeria. IOSR Journal of Business and Management, 17(8), Ver. 1, 25-32.

Pandit, N. R. (2000). Some Recommendations For Improved Research on Corporate Turnaround. Management, $3(2), 31-56$.

Panicker, S., \& Manimala, M. J. (2015). Successful turnarounds: the role of appropriate entrepreneurial strategies. Journal of Strategy and Management, 8(1), 21-40. https://doi.org/10.1108/JSMA-06-2014-0050

Pant, L. W. (1991). An Investigation of Industry and Firm Structural Characteristics in Corporate Turnarounds. 
Journal of Management Studies, 28(6), 623-643. https://doi.org/10.1111/j.1467-6486.1991.tb00983.x

Pearce, I. J. A., \& Robinson, K. (1993). Toward Improved Theory and Research on Business Turnaround. Journal of Management, 19(3), 613-636. https://doi.org/10.1177/014920639301900306

Pedler, M., Burgoyne, J., \& Brook, C. (2005). What has action learning learned to become? Action Learning: Research and Practice, 2(1), 49-68. https://doi.org/10.1080/14767330500041251

Pedler, M., Boydell, T., \& Burgoyne, J. (1989). The Learning Company. Studies in Continuing Education, 11(2), 91-101. https://doi.org/10.1080/0158037890110201

Penrose, E. (1959). The Theory of Growth of the Firm. Oxford: Oxford University Press.

Petrova , E. (2017). Genesis of Strategic Management. Retrieved from Bookboon.com

Pillay, J. (2013). Corporate turnaround as knowledge subversion: a dialogic perspective on transformational change (Unpublished PhD thesis), Cranfield University.

Pires, V., \& Trez, G. (2018). Corporate reputation A discussion on construct definition and measurement and its relation to performance. Revista de Gestão, 25(1), 47-64. https://doi.org/10.1108/REGE-11-2017-005

Raina, B., Chanda, P., Mehta, D., \& Maheshwari, S. K. (2003). Organizational Decline and Turnaround Management. VIKALPA, 28(4), 83-92. https://doi.org/10.1177/0256090920030408

Rangarajan, D., Chonko, L. B., Jones, E., \& Roberts, J. A. (2004). Organizational variables, sales force perceptions of readiness for change, learning, and performance among boundary-spanning teams: A conceptual framework and propositions for research. Industrial Marketing Management, 33, 289-305. https://doi.org/10.1016/S0019-8501(03)00072-5

Ritson, N. (2017). Strategic Management. Bookboon.

Roberts, M. L., Neumann, B. R., \& Cauvin, E. (2017). Individual Performance Measures: Effects of Experience on Preference for Financial or Non-Financial Measures. Advances in Management Accounting, 191-221. https://doi.org/10.1108/S1474-787120170000028007

Rokwell, S. (2016). Revitalizing Organizational Identity to Spark Turnaround. Graziadio Business Review, 19(1), $1-12$.

Rothwell, W., Stavros, J. M., \& Sullivan, R. L. (2016). Organization Development, Transformation, and Change. Practicing Organization Development, 11-25. https://doi.org/10.1002/9781119176626.ch1

Santana, M., Valle, R., \& Galan, J. L. (2018). How National Institutions Limit Turnaround Strategies and Human Resource Management: A Comparative Study in the Airline Industry. European Management Review, 1-13. https://doi.org/10.1111/emre.12177

Saunders, M., Lewis, P., \& Thornhill, A. (2009). Research methods for business students. Essex: Pearson Education Limited.

Schendel, D., Patton, G. R., \& Riggs, J. (1976). Corporate Turnaround Strategies: A Study of Profit Decline and Recovery. Journal of General Management, 3(3), 3-11. https://doi.org/10.1177/030630707600300301

Schmitt, A., \& Raisch, S. (2013). Corporate Turnarounds: The Duality of Retrenchment and Recovery. Journal of Management Studies, 50(7), 1217-1244. https://doi.org/10.1111/joms.12045

Schoenberg, R., Collier, N., \& Bowman , C. (2013). Strategies for business turnaround and recovery: a review and synthesis. Business Review, 25(3), 243-262. https://doi.org/10.1108/09555341311314799

Schuster, F. E., Dunning, K. E., Morden, D. L., Hagan, C. M., Baker, T. E., \& McKay, I. S. (1997). Management Practice, Organization Climate and Performance: An Exploratory Study. The Journal of Applied Behaviural Science, 33(2), 209-226. https://doi.org/10.1177/0021886397332009

Schweizer, L., \& Nienhaus, A. (2017). Corporate distress and turnaround: integrating the literature and directing future research. Business Research, 10, 3-47. https://doi.org/10.1007/s40685-016-0041-8

Senge, P. M. (1990). The Fifth Discipline. New York: Doubleday.

Senge, P. M., \& Sterman, J. D. (1992). Systems thinking and organizational learning: Acting locally and thinking globally in the organization of the future. European Journal of Operational Research, 59, 137-150. https://doi.org/10.1016/0377-2217(92)90011-W

Simerly, R. L., \& Li, M. (2000). Environmnetal Dynamism, Capital Strucure and Performance: A Theoretical Integration and an Empirical Test. Strategic Management Journal, 21(1), 31-49. 
https://doi.org/10.1002/(SICI)1097-0266(200001)21:1<31::AID-SMJ76>3.0.CO;2-T

Slatter, S., Lovett, D., \& Barlow, L. (2006). Leading Corporate Turnaround: How Leaders Fix Turnaround Companies. West Sussex: John Wiley \& Sons Ltd.

Smith, E., Hampson, Y., Chaston, I., \& Badger, B. (2003). Managerial Behavior, Entrepreneurial Style, and Small Firm Performance. Journal of Small Business Management, 41(1), 47-67. https://doi.org/10.1111/1540-627X.00066

Solnet, D. J., Paulsen, N., \& Cooper, C. (2010). Decline and Turnaround: a literature review and proposed research agenda for the hotel sector. Current Issues in Tourism, 13(2), 139-159. https://doi.org/10.1080/13683500802638219

Stritch, J. M. (2017). Minding the Time: A Critical Look at Longitudinal Design and Data Analysis in Quantitative Public Management Research. Review of Public Personnel Administration, 1-26. https://doi.org/10.1177/0734371X17697117

Sudarsanam, S., \& Lai, J. (2001). Corporate Financial Distress and Turnaround Strategies: An Emprical Analysis. British Journal of Management, 12, 183-199. https://doi.org/10.1111/1467-8551.00193

Tenkasi, R., \& Kamel, Y. (2016). To Bankrupcy and Back: Turnaround Strategies for Firm Emergence, Long-Term Survival, and Speed. Research in Organizational Change and Development, 221-259. https://doi.org/10.1108/S0897-301620160000024009

Thompson, A. A., Peteraf, M. A., Gamble, J. E., \& Strickland III, A. J. (2014). Crafting and Executing Strategy. New York: McGraw-Hill Education.

Tikici, M., Omay, E., Derinc, N., Seckin, S. N., \& Cureoglu, M. (2011). Operating turnaround strategies during crisis periods: a research on manufacturing firms. Procedia Social and Behavioral Sciences, 24, 49-60. https://doi.org/10.1016/j.sbspro.2011.09.046

Trahms, C. A., Ndofor, H. A., \& Sirmon, D. G. (2013). Organizational Decline and Turnaround: A Review and Agenda for Future Research. Journal of Management, 39, 1277-1307. https://doi.org/10.1177/0149206312471390

Trochim, W. M. (2006). The Research Methods Knowledge Base (2nd ed.). Internet WWW page. Retrived from http://www.socialresearchmethods.net/kb/

Trujillo, H. J., Baker, J. K., Parachinj, J., \& Chalk, P. (2005). Theory:Organizational Learning as a Four Component Process. In Aptitude for Destruction, Volume 2: Case Stdies of Organizational Learning in Five Terrorist Groups. Santa Monica, CA, Arlington, VA; Pittsburgh, PA: RAND Corporation.

Ukaidi, C. A. (2016). Turnaround Strategy and Corporate Performance: A Study of Quoted Manufacturing Companies in Nigeria. European Journal of Business and Management, 8(19), 81-94.

Valipour, H., Birjandi, H., \& Honarbakhsh, S. (2012). The Effects of Cost Leadership Strategy and Product Differentiation Strategy on the Performance of Firms. Journal of Asian Business Strategy, 2(1), 14-23.

Venkatraman, N., \& Ramanujam, V. (1986). Measurement of Business Performance in Strategy Research: A Comparison of Approaches. The Academy of Management Review, 11(4), 801-814. https://doi.org/10.5465/amr.1986.4283976

Wandera, J. O., Sakwa, M. M., \& Mugambi, F. M. (2017). Turnaround Strategies and Organizational Performance: A Study of Cause-Effect Relationship. International Journal of Recent Research in Commerce, Economics and Management, 4(4), 391-400.

Wanyonyi, B. M., \& Nyakweba, B. O. (2016). Assessment of Turnaround Strategy on Organizational Performance: A Case of Kenya Industrial Estates, Kenya. The International Journal of Business \& Management, 4(10), 354-360.

Watanabe, R. M., \& Senoo, D. (2008). Organizational characteristics as prescriptive factors of knowledge management initiatives. Journal of Knowledge Management, 12(1), 21-36. https://doi.org/10.1108/13673270810852368

Whitney, J. O. (1987). Turnaround Management Every Day. Harvard Business Review.

Wittig, T. (2017). Crisis and Turnaround in German Medium-Sized Enterprises: An Integrated Empirical Study. Springer Fachmedien Wiesbaden GmbH, 12- 45. https://doi.org/10.1007/978-3-658-16386-0

Yadav, S., \& Agarwal, V. (2016). Benefits and Barriers of Learning Organization and its five Discipline. IOSR 
Journal of Business and Management (IOSR-JBM), 18(12), Ver. I, 18-24.

Yildiz, S., \& Karakas, A. (2012). Defining Methods and Criteria for Measuring Business Performance: A Comparative Research Between Literature in Turkey and Foreign. Procedia Social and Behavioural Sciences, 58, 1091-1102. https://doi.org/10.1016/j.sbspro.2012.09.1090

Zott, C., \& Amit, R. (2008). The Fit Between Product Market Strategy and Business Model: Implications for Firm Performance. Strategic Management Journal, 29, 1-26. https://doi.org/10.1002/smj.642

\section{Copyrights}

Copyright for this article is retained by the author(s), with first publication rights granted to the journal.

This is an open-access article distributed under the terms and conditions of the Creative Commons Attribution license (http://creativecommons.org/licenses/by/4.0/). 